DOI: https://doi.org/10.37816/2073-9567-2020-57-72-85

УДК 008+ 821.161.1.0

ББК $71+83.3(2 \mathrm{Poc}=$ Рyс $) 53+85$

This is an open access article distributed under

the Creative Commons Attribution 4.0

International (CC BY 4.0)

(C) 2020. Natalia A. Drovaleva

Moscow, Russia

\title{
V. Ia. BRIUSOV AND THE SYNTHESIS OF ARTS (REGARDING HIS WORK ON THE NOVEL “THE FIERY ANGEL")
}

\begin{abstract}
This paper focuses on the visual component in the edition of V. Ia. Briusov's novel "The Fiery Angel" published in the author's lifetime (1909). It aims to characterize Briusov's work with verbal and graphical aspects while creating the novel viewed as a synthetic, two-sided entity, in which the appearance and structure are fused with its actual contents. The idea of mutual enrichment of literature and visual arts was one of the key ideas in the artistic vision of writers of the 20th century. It was the artistic amalgam that they sought, which allowed them to organically develop it into an entirely new technique and the language they needed to embody their new vision of the world and further their understanding of the artistic process. By analyzing the particularities of the images that Briusov introduced in this edition and the meticulous work he conducted portraying characters in the text, the author comes to a conclusion that the involvement of various materials allowed the writer to use "material metaphors" to start a polylogue with the text considering the multitude of styles, themes and emotions. Both consciously and subconsciously Briusov connects the features of "languages" of various arts, thus paving the road to a new organic form of art, about which he wrote in the article, dedicated to K. D. Balmont's poetry "Let Us Be Like the Sun!".
\end{abstract}

Keywords: synthesis of arts, publishing, symbolism, printing, costume, V. Ia. Briusov, "The Fiery Angel".

Information about the author: Natalia A. Drovaleva - Senior Researcher, A. M. Gorky Institute of World Literature of the Russian Academy of Sciences, Povarskaya St. 25 a, 121069 Moscow, Russia; Post-graduate Student at the Department of Theory of Literature, Philological Faculty, Lomonosov Moscow State University, Leninskie Gory 1, bld. 51, 119991 Moscow, Russia. ORCID ID: https://orcid.org/0000-00021095-2991. E-mail: n.drovaleva@mail.ru

Received: April 29, 2020

Date of publication: September 28, 2020

For citation: Drovaleva N. A. V. Ia. Briusov and the Synthesis of Arts (Regarding his Work on the Novel "The Fiery Angel"). Vestnik slavianskikh kul'tur, 2020, vol. 57, pp. 72-85. (In English) DOI: https://doi.org/10.37816/2073-9567-2020-57-72-85 
$* * *$

\title{
(C) 2020 г. Н. А. Дровалева
}

г. Москва, Россия

\section{В. Я. БРЮСОВ И СИНТЕЗ ИСКУССТВ (О РАБОТЕ НАД ИЗДАНИЕМ РОМАНА «ОГНЕННЫЙ АНГЕЛ»)}

\begin{abstract}
Аннотация: Статья посвящена визуальной составляющей в прижизненном издании романа В. Я. Брюсова «Огненный ангел» (1909). Задача настоящей статьи охарактеризовать работу Брюсова со словом и графикой в произведении с учетом синтетических взглядов на книгу как особую двоякую сущность, внешний вид и структура которой неотделимы от содержания. Идея взаимообогащения искусства слова и живописи - одна из ключевых в художественном сознании писателей XX в., искомое соединение, из которого органически вырастает качественно новая и самоценная техника, рождающая искомый язык нового видения мира и понимания художественного творчества. В результате анализа особенностей избираемой Брюсовым техники изображений, помещенных в издании, а также тщательной работы писателя с портретными характеристиками героев в тексте, автор статьи приходит к выводу о том, что привлечение различных материалов дает возможность использовать «материальные метафоры» для вступления в полилог с текстом произведения в связи с многочисленными стилями, темами и областями чувств. Осознанно и неосознанно Брюсов соединяет особенности языков разных видов искусств, в результате чего прокладывает дорогу к новому искусству, о котором он писал во вступительных строках к статье о К. Д. Бальмонте «Будем как солнце!».
\end{abstract}

Ключевые слова: синтез искусств, книгоиздание, символизм, гравюра, костюм, В. Я. Брюсов, «Огненный ангел».

Информация об авторе: Наталия Алексеевна Дровалева - старший научный сотрудник, Институт мировой литературы им. А. М. Горького Российской академии наук, ул. Поварская, д. 25 a, 121069 г. Москва, Россия; аспирант кафедры теории литературы филологического факультета, Московский государственный университет им. М. В. Ломоносова, ул. Ленинские горы, д. 1, стр. 51, 119991 г. Москва, Россия. ORCID ID: https://orcid.org/0000-0002-1095-2991. E-mail: n.drovaleva@ mail.ru

Дата получения статьи: 29.04.2020

Дата публикации: 28.09.2020

Для цитирования: Дровалева Н. А. В. Я. Брюсов и синтез искусств (о работе над изданием романа «Огненный ангел») // Вестник славянских культур. 2020. Т. 57. C. 72-85. DOI: https://doi.org/10.37816/2073-9567-2020-57-72-85

The concept of mutual enrichment of literature and visual arts was one of the key ideas in the artistic vision of writers of the $20^{\text {th }}$ century. It was the artistic amalgam they sought, which allowed them to organically form it into an entirely new technique and the language they needed to embody their new vision of the world and their understanding of the artistic process $[11 ; 12]$.

The idea of a creative person being a "consonance of gifts" was one of the most productive ideas of the Silver Age, where symbolism, acmeism and futurism worked together 
under the banner of community of muses. Synthetic forms of art, such as theater, opera, ballet, architecture and publishing were flourishing. A. A. Blok in his article "Bereft of God, of Inspiration" (1921) summarized the previous decades with the following words: "In Russia, painting, music, prose and poetry are inseparable, and philosophy, religion, society and even politics are indistinguishable from them. Together they form a united, powerful stream that carries the precious weight of national culture" [3, p. 176]. Creative people became "universal artists" who mastered or at least attempted to master all the possible languages of art. Poets and writers borrowed the arsenal of artists by inserting color palette in their prose and poetry, and artists wrote texts basd on their paintings (M. A. Voloshin, K. A. Korovin). Famous modernist architects of this time not only created projects of houses and homesteads, they also planned the interiors, drew sketches of furniture, wallpapers, stained-glass windows and forgings. Accomplished modernist painters did not limit themselves to painting, they also tried their hand in architecture and theater (M. A. Vrubel made frescoes, panels, theatrical decorations and illustrated books, while S. V. Malyutin established a woodworking workshop that created furniture based on his sketches) [14].

V. Ia. Briusov, who might seem disinterested in painting and graphical arts at first, was in fact the author of numerous drawings and sketches that employed various techniques. M. B. Shaposhnikov published some of his works in the book "P. S. Solov'eva. V. Ia. Briusov. M. A. Voloshin. A. A. Blok. A. Bely" (2016). It includes training sketches, pictures of fantastic creatures, landscapes and portraits of contemporaries, made with pencil, ink and quill. Briusov does not employ color (watercolor or pencils) in his work, he often draws only the outlines of objects and highlights important details by applying more pressure to the pencil.

It is known that Briusov's archive contains lithographs and drawings by A. Kubin. The most common themes of his dark and gloomy drawings made between 1900 and 1905 are sleep, life and death and other worlds. M. B. Shaposhnikov believes that "Briusov enjoyed the mystical and tense style of the Austrian painter and his own drawings became something of an imitation of the graphical works" [20, p. 81] of Kubin. For example, a drawing of a figure in monk's robe and Death (1906), created when Briusov was working on "The Fiery Angel", indeed resembles the style of Kubin's early works (figures 1-2).

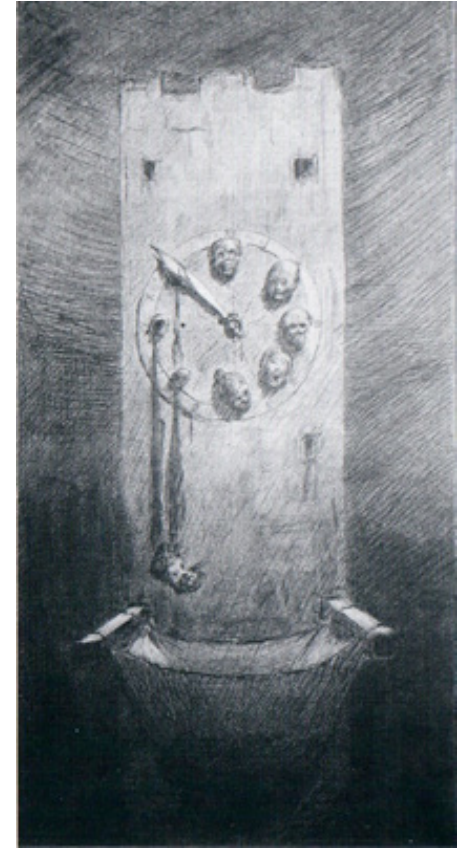

Иллюстрация 1 - А. Кубин. Рисунок. 1905 г. [20, с. 79]

Figure 1 - A. Kubin. Drawing. 1905 [20, p. 79] 


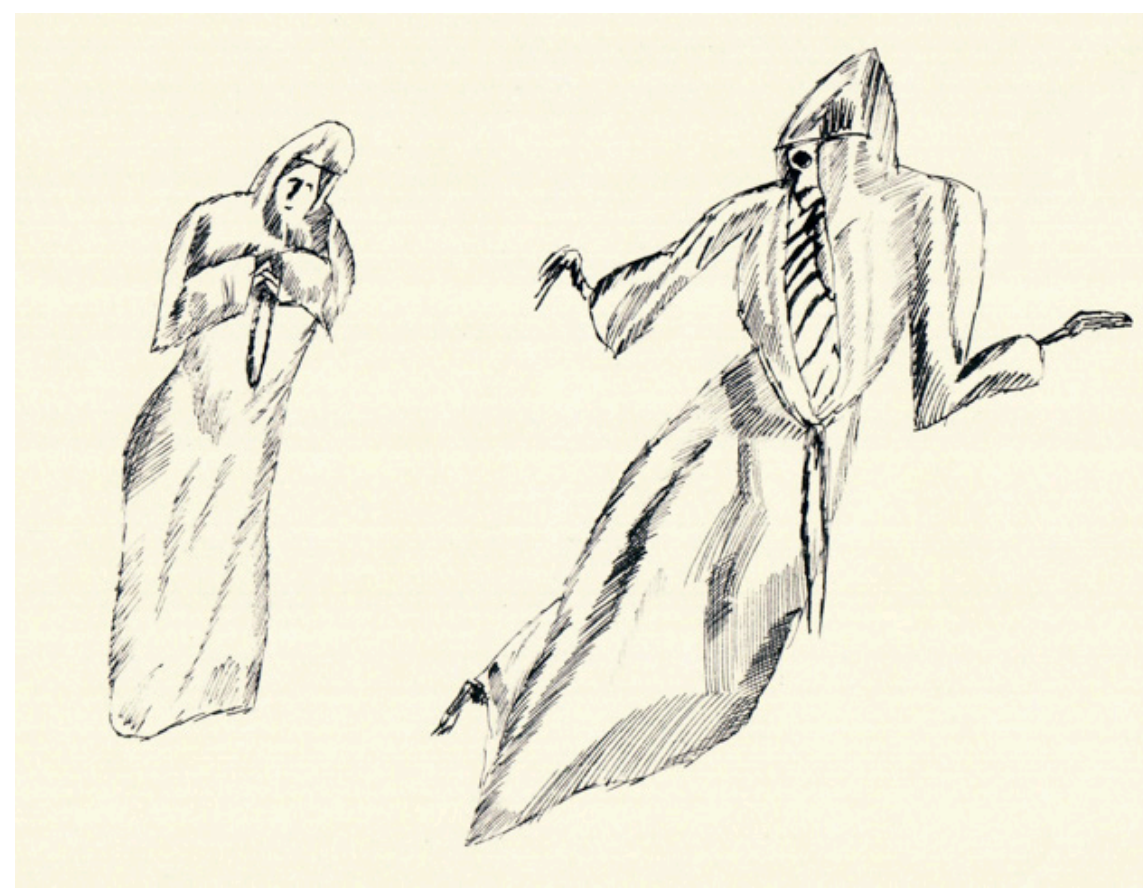

Иллюстрация 2 - В. Я. Брюсов. Фигура в монашеской рясе с четками в руках и Смерть. 1906 г. Бумага, чернила [20, с. 78]

Figure 2 - V. Ia. Briusov. A Figure in monk's robes with a rosary and Death. 1906. Paper, ink. [20, p. 78]

Typography and publishing was very important for Briusov, he maintained close contact with Russian and foreign artists who made vignettes for "Vesy". Along with "Vesy" and his editorial activities in the publishing house, Briusov worked hard on his own collections. A book ceased to be a book in its most common understanding, it became an organic followup to the very essence of the poet, hence the close attention to publishing. Books were often accompanied by notes and comments. For example, "Urbi et Orbi" had an extravagant note (according to G. A. Tolstykh) that simply read "This edition will not be repeated" [17, p. 216]. Similar notes used to be included in western bibliophilic editions and signified the unique nature of the author's accomplishments. Briusov needed such eccentricity in order to present symbolism as an important literary phenomenon and to "mythologemically legitimise himself within the circle of institutional artistic lawmakers as a notable figure, as one of the powerful Influencers of contemporary Russian art" [10, p. 142].

The aim of this article is to characterize Briusov's ideological and technical work on the textual and graphic aspects of a book in "The Fiery Angel" (the 1909 edition), viewing the book from a synthetic standpoint, as a unity of verbal and graphic materials.

A book is a special, two-sided entity, whose "material base (appearance and structure) is constructively inseparable from its contents (information and purpose), which differentiates it from every other form of mass media" [8, p. 12]. E. V. Zavadskaya in one of her works writes that for Jorge Borges, for example, each letter in a book was not a dress for a thought, but rather "a given thought itself" [9, p. 216]. Thus, a reader's response is generated by the textual component of a work, enclosed in a book form.

It is worth noting beforehand that the concept of synthesis of arts does not mean simple superficial coexistence of various forms of art and techniques. V. A. Favorskiy, a theorist and historian of art and an engraver, who studied the topic of synthesis of arts in theory 
and practice, described the mechanics of fusing various languages of art as follows: "Each sensory field has its own method of perception, its own structure; by fusing together they break down this structure and turn reality into chaos and disorder. Only a complex of methods can give shape to the entirety of reality. The methods fuse into one system, forming certain ties in specific order, relying on each other, connecting but never fully blending together" $[18$, p. 279]. Simultaneous usage of different languages of art stimulates the appearance of numerous material metaphors, "relating to various sensory fields and themes; first of all, the connection between a given work of art and our actual reality, our physical forms becomes more apparent; second, it makes the dialectic structure of the world even more apparent" [18, p. 281]. Favorskiy uses work on the decoration of one's own book or on a text of another author as an example.

In the case of the 1909 edition of "The Fiery Angel", Briusov worked on inserting the book in its entirety in the context of medieval art. The edition of 1908 that consisted of two books included original vignettes by J. Sattler. Working on the 1909 edition, Briusov deliberately chose prints from the 15 th and 16 th centuries (the time period in which the novel is set) as illustrations [4]. He wrote about it in the prefix to the second edition. Briusov's collected works in seven volumes, edited by P. G. Antokol'skiy, A. S. Myasnikov, S. S. Narovchatyy and N. S. Tikhonov, includes a note saying that the text of "The Fiery Angel" is provided in accordance to the original edition of the 1909 [19, p. 349], however the text prepared for publishing in the fourth volume does not mention the prints (the list of illustrations is given in the end of the 1909 edition). "The Prefix to the Russian Edition" is said to have been taken from the 1909 edition, but in it the prefix was titled "The Prefix to the Second Edition". The authors of the collected works decided to omit Briusov's notes and comments to the prefix of the 1909 edition on the subject of aims and scopes of this new edition, but we believe that they should be mentioned in our research. In particular, Briusov believes that it is important to point out that this edition includes various materials that can shed some light on the time period that the novel is set in, and that "the decorations in the book copy the prints of late $15^{\text {th }}$ and $16^{\text {th }}$ centuries. The only exception is one print from the early $17^{\text {th }}$ century that we had to use because we were unable to find an older printed portrait of Faust" [4, p. VIII].

It is known that this edition of "The Fiery Angel" (1909), decorated by Briusov himself, sparked controversy among his contemporaries. A. Ia. Levinson, a correspondent of the "Sovremenny Mir" magazine, wrote on the subject of applied art of book publishing that cannot substitute true art. He believed that imitating antique binding with cabbalistic symbols and decorating the pages of the book overshadowed the artistic value of the novel itself [4, p. 347], however it only proved that such decorations did not go unnoticed. Briusov also passed on his reverence towards books to the protagonist, Ruprecht. He considers books to be the true treasure of humanity and enjoys Glok's lectures on the features, pros and cons of various fonts (gothic, roman, antiqua, bastard and italic). Briusov's aims were out of reach for regular critics. The prints that he chose create a certain presentive perception of images historically and ethnographically accurate depictions of "a German farmer of the $16^{\text {th }}$ century, a lady and a lansquenet" [1, p. 97].

History becomes the subject of artistic depiction, Briusov introduces the historical images into the novel not only through text, but also through typography. One of Briusov's aims was a so-called "expansion". Book publishers believe that in both fiction and non-fiction any kind of illustration, which serves to explain any part of the text, performs the function of expansion by its very definition. An illustration always "expands" the information contained 
in a text by providing additional information that the text lacks, however the key points for illustrations do not always coincide with key points of plot development or introductions of new characters. For example, Briusov puts a portrait of Erasmus of Rotterdam in the prefix, yet he is not a character in the novel, only his works are mentioned there [1, p. 9]. The portrait is minimalistic with very few details, but it is made in the style of xylography, which was characteristic for portraits and illustrations in books in the novel's alleged time period. Briusov's task in this case consisted of selecting a suitable existing picture that would correspond with the selected historical era and style in general [6, p. 158-159] (figure 3).

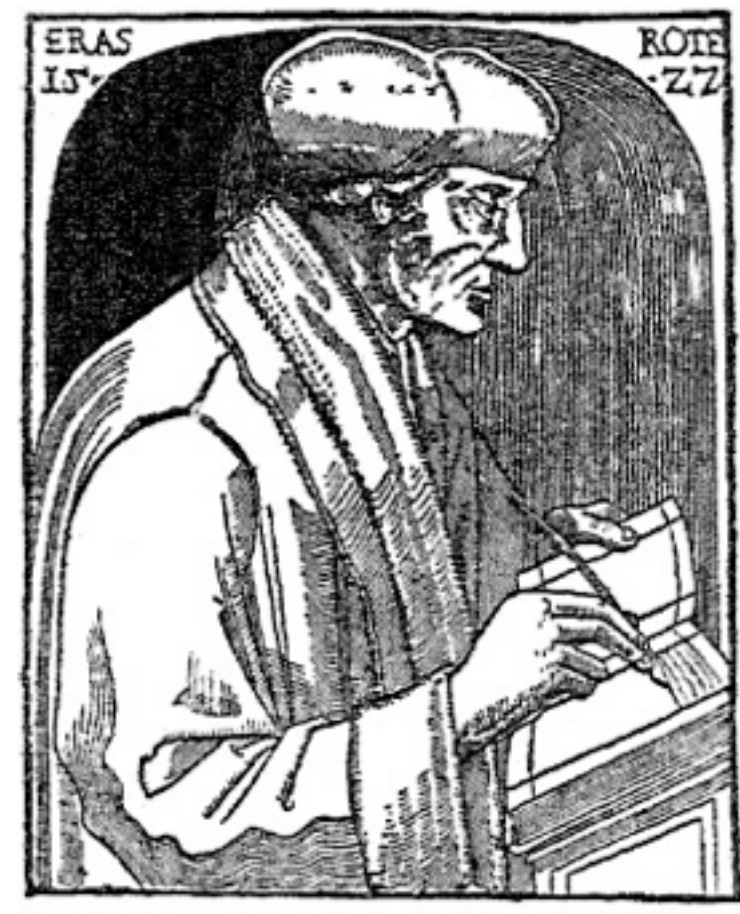

Иллюстрация 3 - Изображение Э. Роттердамского, помещенное в предисловии к роману «Огненный ангел» (1909). Гравюра $[4$, с. 5]

Figure 3 - Picture of Erasmus of Rotterdam from the prefix to "The Fiery Angel" (1909). Print [4, p. 5]

The other task of an author who chooses to decorate their own works is, however, considerably more difficult. It can be very problematic to find the appropriate pictures that convey a specific meaning and are made in the style the author needs. All the portraits included in the 1909 edition are prints.

V. V. Pakhomov in the second part of "The Art of Book", sub-titled "Illustration", formulates an issue of "how and to what degree the compositional and descriptive methods of an artist correspond with those of the author of a given literary work" [16, p. 317]. He believes that this topic is not studied enough and therefore scholars have to study "the entirety of an artist's arsenal of graphical and compositional methods: line, shape, light, color, methods of depicting objects, space, etc. that were used to create an image, in their typical and not specific form, i.e. as a characteristic graphical system, applied to the understanding of a given literary work" [16, p. 318]. "Characteristic graphical system" is the key concept in illustrating a work of art. Pakhomov uses illustrations to Ancient Greek myths as an example. He believes that it can prove useful to study the forming of connections between illustrations and literary material in modern history, to what degree the illustrations correspond with mythology, what new aspects of it the artists see and what graphical methods they use. The structure of images in myths leads to certain graphical peculiarities: "It is impossible to imagine the events unfolding in myths as real, in a real artistic sphere and in real picturesque color" [16, 
p. 328]. The best way to convey the greatness of this imagery is with a simple line that defines the silhouette and nominally creates volume and space. Pakhomov believes that printing, characterized by its integrity and monumental nature, is the best technique in this case. The specifics of such form of art as printing (especially in the form of an illustration) is impossible to comprehend without understanding the mechanics of its appearance, usage, creation and perception ${ }^{1}$.

Publishers begin to use plates (a form of prints) as book illustrations in the first century of the existence of printing (the $15^{\text {th }}$ century). At this time only two types of prints existed in Europe: engraving (cutting prints on metal) and xylography (prints on wood). Engraving was more popular in the South, while xylography was mostly used in the North (most notably in Germany). A. A. Leshchinskiy believes that "xylography and its plastic language are still closely tied to medieval art, while engraving embodies the primary tendencies of the Renaissance" [13, p. 51]. Xylographical techniques correspond to the German graphical style of the middle of $15^{\text {th }}$ century. The drawings consist of "straight, rigid lines, clothing folds often end up in pointy hooks or split up, turning into something resembling tree branches" [15, p. 82]. Lighting and shades are often missing, but the contour is occasionally supplemented by parallel strokes or strips of shade from ceiling beams. Images have graphical perspective, but it is very simplistic [15, p. 82]. Early xylography was closely tied to publishing, while engraving quickly transcended the boundaries of books. A wooden board with a relief painting is similar to a typographical form, which is why it was used in printing book illustrations. Yu. Ia. Gerchuk in his "History of Graphics and the Art of Book" writes that "despite its simplicity, early xylography became an integral and organic form of art right away", and "its laconic graphical language, characterized by flatness and the type and scale of its pointy strokes, was born from the natural properties of the material and tools" [7, p. 140]. Another characteristic property of xylography is its "relative independence from the book, for which it was originally created, from its place in the printing form" [7, p. 155]. The schematic nature of early printed illustrations is symbolic, rather than graphical (unlike paintings, for example). This was the reason for the expansion of printing's possibilities, when the same picture "could depict, depending on the context, different characters, locations and events" [7, p. 156]. As an example, Gerchuk uses Hartmann Schedel's "World Chronicle" (late 15th century), where one portrait is attributed to one of the biblical forefathers, Homer's protagonist, a Roman poet and a German knight. The contemporary reader evidently didn't need the authentic depiction of images and events, "being satisfied with having at least approximate graphical parallels to the events, mentioned in the text" [7, p. 157-158]. The very act of connecting a verbal image with its graphical counterpart was what created the feeling of integrity and believability.

Xylography returns on the turn of the $20^{\text {th }}$ century, overshadowing the impressionist etching and the decorative lithography, losing the reproductory role and gaining (technically speaking, copying it from ancient prints) new meaning and aesthetic functions. Artists that decorated collections of poetry turned to the traditions of medieval printing, fusing its features with the graphic language of their contemporary artistic schools: "A classic example of cooperation between a poet and an artist is „Bestiary, or the Procession of Orpheus” (1910) by G. Apollinaire with cropped xylographies by R. Dufy, which magnificently combined the antique tradition of medieval animal transformations with the graphic language of the age of cubism" [7, p. 266].

Indeed, the black and white xylography, light with artistic details, provided numerous new possibilities for a dialogue between text and picture. The images that appeared in the

${ }^{1}$ Due to the specifics of this research it primarily focuses on the history of xylography. 
text became more colourful and picturesque against a printed background. For example, the character portraits in "The Fiery Angel" are simplistic yet colorful, compared to the prints that Briusov chose as illustrations for the book. This is a result of his meticulous work with historical documents, depicting the appearance of farmers and villagers in "The Fiery Angel" time period.

It is well known that Briusov drew maps and sketches of houses and costumes himself when he was studying the land, dwellings and appearance of characters for "The Fiery Angel"2. There are preserved sketches of Ruprecht and Renata's home in Cologne (they depict an altar, a bed, a closet, a corridor and a fireplace) and "portraits" of Germans of the $16^{\text {th }}$ century. K. A. Barsht points out this type of work, which is essentially a synthetic fusion of literature and artistic techniques, as a separate and significant point in his article "On the Typological Connections between Literature and Painting (on the Materials of Russian Art of the $19^{\text {th }}$ Century)": "A writer turns to drawing as a phase of working on their literary work" [2, p. 11].

The two pictures were published in V. Ia. Briusov's collected works, in the fourth tome, which is dedicated to "The Fiery Angel". However, these drawings were put there by publishers and editors, who worked on this collection. Briusov indeed drew sketches that he apparently needed to visualize the aspects of the novel, such as costumes of that era, more clearly, and not as illustrations for the novel. Apart from the sketches in the Manuscript Department of the RSL (Fund 386), a number of other sketches and drawings were successfully preserved: a drawing of a man on a balcony ${ }^{3}$, that corresponds with the plot of "The Fiery Angel" (in the $12^{\text {th }}$ chapter a lonely Ruprecht cries on a balcony of the von Vellen castle [5, vol. 4, p. 220-221]), an unshaded drawing of an archbishop ${ }^{4}$ (the $13^{\text {th }}$ chapter deals with the arrival of archbishop of Trier). The pages 11-13 and 18-19 bear complete or partial sketches of costumes and hairstyles drawn in ink and supplemented by verbal descriptions of details and color palettes of various dresses. In order to reproduce them Briusov studied the publication of Friedrich Hottenroth, a historian and engraver, titled "Deutsche Volkstrachten, städtische und ländliche, vom XVI. Jahrhundert an bis zum Anfange des XIX. Jahrhunderts"s. He was primarily interested in the costumes of Western Germany, specifically Cologne and its surrounding area, which Hottenroth described in the second volume of his book, titled "Volkstrachten aus West- und Nordwest-Deutschland" (1900). Apart from the drawings of groups of people, a Jew, a peasant woman with a goose, various boots and headdresses (apparently belonging to craftsmen) ${ }^{6}$, Briusov also left sketches of a doctor, an innkeeper, a townswoman, noble ladies and a peasant from the outskirts of Cologne. The sketch of the doctor is accompanied by a note "Clad in all black". He wears a cape and a round hat. There is a description of the doctor who treated Ruprecht in the novel: "Visitors knocked on our door more often that we would expect, because Mathew, slightly shamed by my misfortune but still full of his healthy energy and kind-hearted joy, visited me every day, and so did Lucian Stein who persistently inquired about my ilness in order to report my condition to count Heinrich. Lastly, i was visited daily by a doctor, invited here by Mathew, who wore a black cape and a round hat, a pedantic and ignorant man, to whom I owe my life in the least possible amount" [5, vol. 5, p. 164]. Later on Ruprecht will call him "the black doctor". Thus, Briusov's sketch received a verbal representation in the novel (figures 4,7 ).

\footnotetext{
${ }^{2}$ Manuscript Department of the RSL. Fund 386. Box 32. Storage unit 12.

${ }^{3}$ Manuscript Department of the RSL. Fund 386. Box 32. Storage unit 12. Page 8.

${ }^{4}$ Manuscript Department of the RSL. Fund 386. Box 32. Storage unit 12. Page 9.

${ }^{5}$ The name of historian F. Hottenroth is written on one of the pages with a colored drawing of a costume.

${ }^{6}$ Manuscript Department of the RSL. Fund 386. Box 32. Storage unit 12. Page 12.
} 


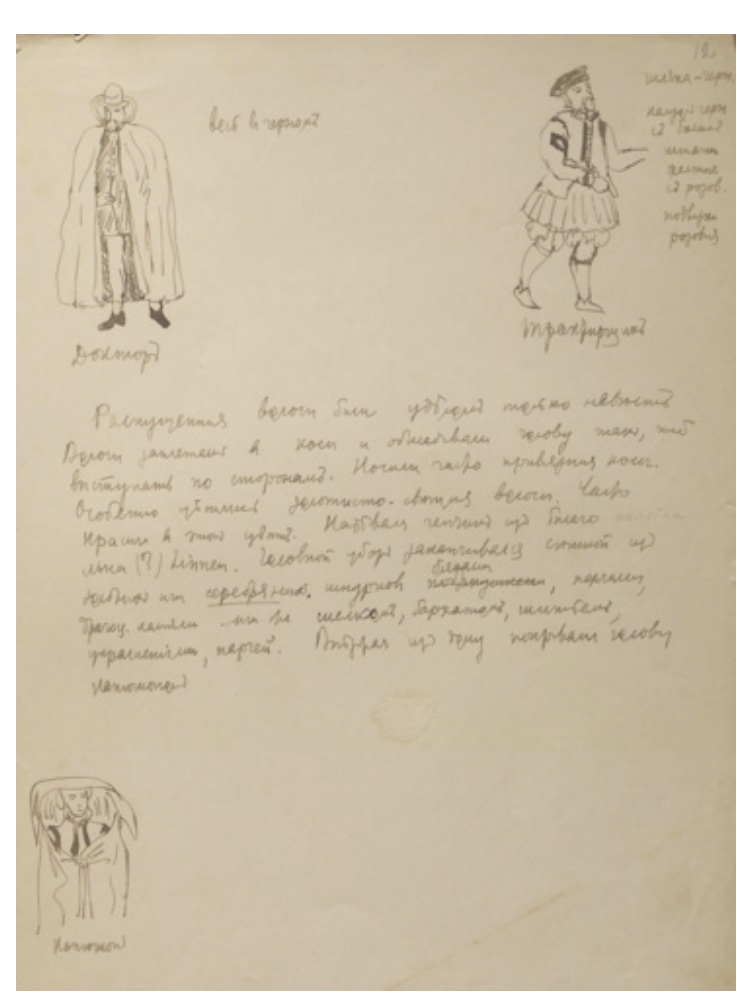

Иллюстрация 4 - В. Я. Брюсов. Зарисовки. Материалы к роману «Огненный ангел». Доктор, трактирщик, дама в капюшоне [НИОР РГБ. Ф. 386. Ед. xp. 12. Л. 12]

Figure 4 - V. Ia. Briusov. Sketches. Materials to "The Fiery Angel". Doctor, Innkeeper, Hooded Woman [Manuscript Department of the RSL. Fund 386. Storage unit 12. Page 12]

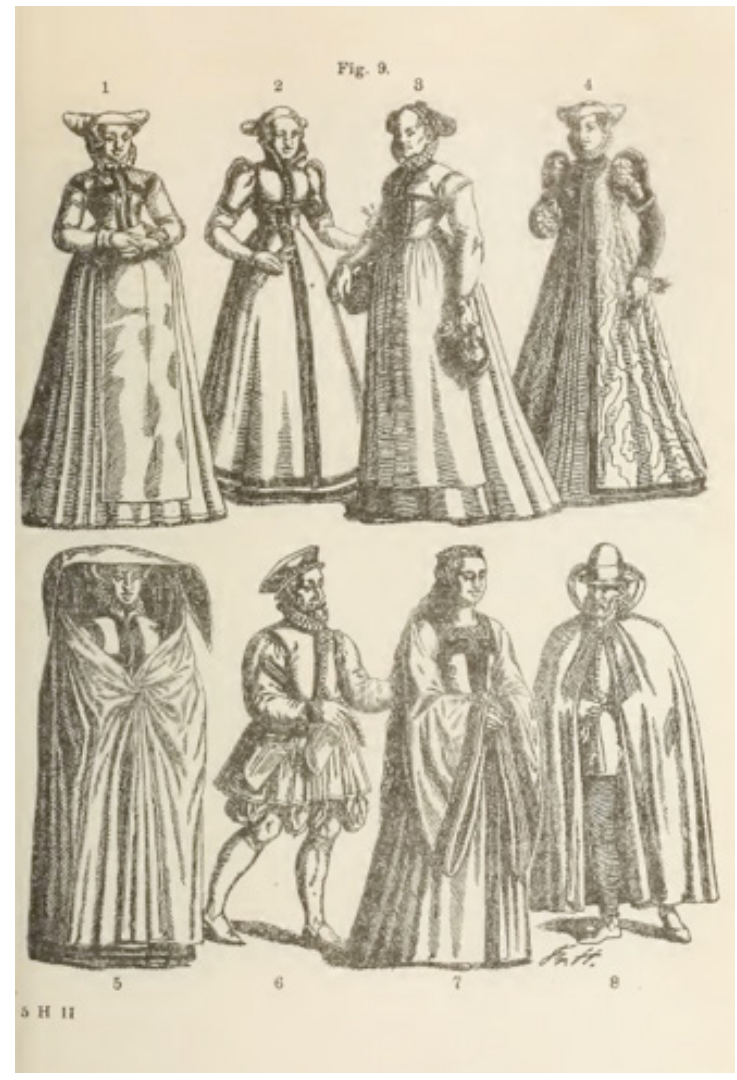

Иллюстрация 7 - Рисунок Ф. Готтенрота. Горожане г. Кельна. Среди них - знатная дама в плаще с широким капюшоном, доктор в круглой шляпе и плаще [21, с. 65]

Figure 7 - Drawing by F. Hottenroth. Citizens of Cologne. Among them are a noblewoman in a cape with a wide hood and a doctor in a round hat and a cape $[21$, p. 65]

There is a drawing of an innkeeper on the same page, with the main colors of his costume listed underneath: "Hat — black, black jacket, yellow and pink pants, pink garters" However, the description of his clothing didn't make it into the novel.

${ }^{7}$ Manuscript Department of the RSL. Fund 386. Box 32. Storage unit 12. Page 12. 
Briusov also writes here the following: "Loose hair were strictly an attribute of brides. Women made their hair in braids and wrapped them around so that they would stick to the sides. They often wore false braids. Bright golden hair was especially popular. Women often dyed their hair in this color. They wore bonnets of white ${ }^{8}$ linen ${ }^{9}$. A headdress would end with a net of golden and silver cords, badges, pearls, gemstones or silk, velvet, needlework, decorations or brocade. On leaving the house women would cover their heads with a hood"10. Below there is a drawing of a hooded woman. A very similar drawing can be found illustrating the text of F. Hottenroth's "Volkstrachten aus West- und Nordwest-Deutschland" [21, p. 65]. Briusov's text is essentially a short synopsis of the description of women's costumes and headdresses given in Hottenroth's book. The colored sketch that he made is a copy of a drawing, included by Hottenroth in the addendum to his edition ${ }^{11}$. It is a drawing of a woman, dressed in a long blue hooded cloak and a blue and pink blouse. A loose hood is a constant part of Renata's clothing, which allows her to protect her hairstyle. Near the end of the first chapter of "The Fiery Angel" the heroine appears, dressed as an elegant noblewoman (vornehme frau): "While I was standing in front of the hostess who kept complaining and did not know what to do, the door of the house suddenly opened and Renata appeared on the doorstep. She was dressed in a long blue silken cape with a hood that covered her face and a pink blouse with white and dark blue decorations, just how the rich women of Cologne used to dress" [5, vol. 5, p. 35]. Thus, Briusov almost identically recreated the aforementioned visual image in verbal form (figures 5,6 ).

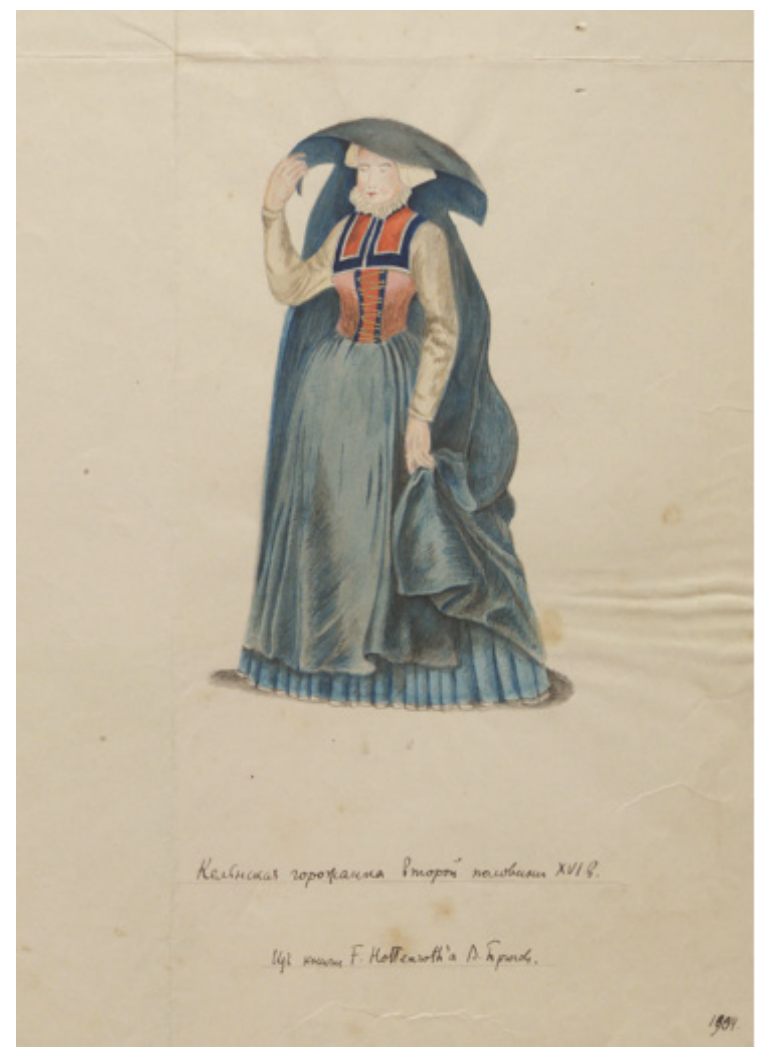

${ }^{8}$ Later on, a comment saying "fabrics" was written below in pencil.

9 The text says "Linnen".

${ }^{10}$ Manuscript Department of the RSL. Fund 386. Box 32. Storage unit 12. Page 12.

${ }^{11}$ Manuscript Department of the RSL. Fund 386. Box 32. Storage unit 12. Page 19. The drawing was copied from the one in Friedrich Hottenroth's book. Addendum, drawing (tafel) 24.
Иллюстрация 5 - Изображение женщины из книги Ф. Готтенрота, сделанное рукой В. Я. Брюсова. 1904 г. [НИОР РГБ. Ф. 386. Ед. хр. 12. Л. 19]

Figure 5 - Drawing of a woman from F. Hottenroth's book, made by Briusov. 1904 [Manuscript Department of the RSL. Fund 386. Storage unit 12. Page 19] 


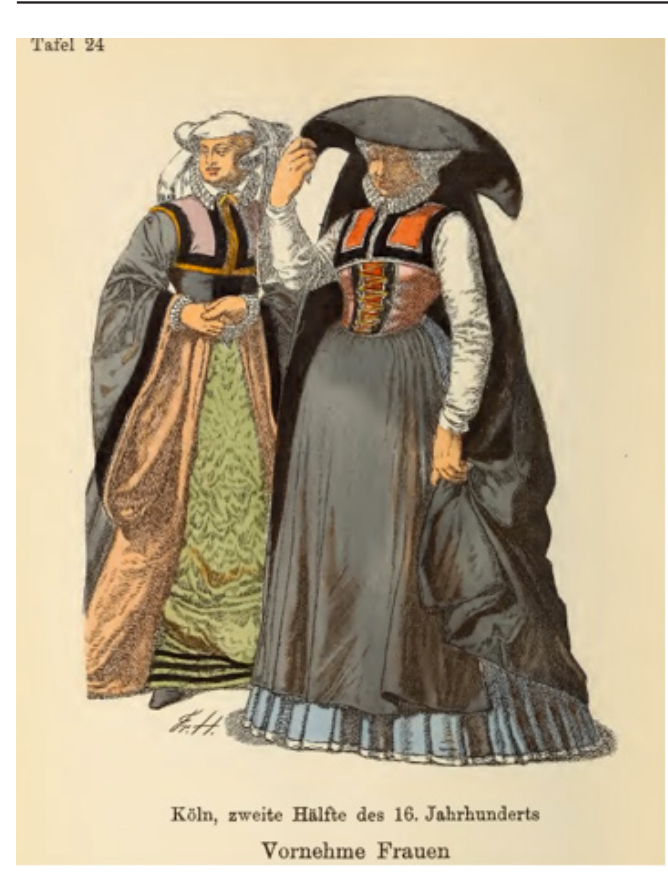

Иллюстрация 6 - Рисунок Ф. Готтенрота. Знатные дамы. Приложение. Изображение 24 [21]

Figure 6 - Drawing by F. Hottenroth. Noblewomen. Addendum. Figure 24 [21]

Briusov gives the following portrait (of Mathew's sister, who Ruprecht meets in the 8th chapter), based on the description of traditional appearance of a woman from the suburbs of Cologne: "When we walked through the dining room full of old, heavy German furniture, a young girl in a pink dress, green apron and a golden belt suddenly ran out of the adjacent room and upon seeing us stopped, clearly embarrassed, not knowing what to do. Her slim, tender figure, childish oval face with long jagged eyelashes above her blue eyes, golden braids, laid under a white bonnet, all of it looked to me, tortured by the images of anguish, used to the faces distorted with lust and desperation, the way an angel's flight must look to the damned souls, waiting at the entrance to hell. I stood there, confused, not knowing whether I should just walk past her or bow, or maybe speak to her, and Mathew laughed uproariously, witnessing our confusion" [5, vol. 5, p. 152]. On the one hand, such portrait recreates the appearance of a typical citizen, which, according to the intentions of notorious mystifier Briusov, would refer the readers to the novel's time period, and on the other hand it points out the tortured facial features of Renata, juxtaposing them to those of a beautiful girl, almost a child, who represents the traditional image of a blonde girl (figure 8).

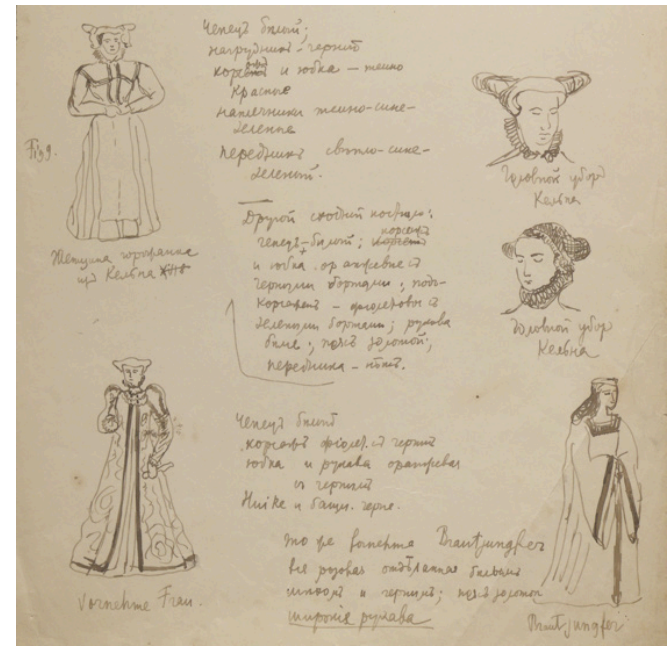

Иллюстрация 8 - В. Я. Брюсов. Изображения женских причесок жительниц г. Кельна, описание цветового решения [НИОР РГБ. Ф. 386. Ед. хр. 12. Л. 14] [Figure 8 - V. Ia. Briusov. Drawings of women of Cologne's hairstyles and a description of their color schemes [Manuscript Department of the RSL. Fund 386. Storage unit 12. Page 14] 
Thus, the text of this literary work, the detailed verbal descriptions of costumes and Briusov's ideas regarding the typography of "The Fiery Angel", which were realized by him choosing the early examples of prints and including them in the 1909 edition of the novel, engage in a polylogue. The usage of various materials allows the writer to use "material metaphors" to start a dialogue with the text in regards to the multitude of styles, themes and emotions.

Both consciously and subconsciously Briusov connects the features of "languages" of various arts, thus paving the road to a new form of art, about which he wrote in the article, dedicated to K. D. Balmont's poetry "Let Us Be Like the Sun!" [5, vol. 6, p. 374-375]. The book culture changed dramatically after the symbolists. Futurists, for example, learned a lot from them and went even further with their ideas (for example, making books completely by hand, from illustrations to covers).

\section{СПИСОК ЛИТЕРАТУРЫ}

1 Барковская Н. В. Поэтика символистского романа. Екатеринбург: Изд-во УрГПУ, 1996. $285 \mathrm{c}$.

2 Баршт K. A. О типологических взаимосвязях литературы и живописи (на материале русского искусства XIX в.) // Русская литература и изобразительное искусство XVIII - начала XX в. Собр. научн. тр. Л.: Наука, 1988. С. 5-48.

3 Блок А. А. Собр. соч.: в 8 т. М.; Л.: Гослитиздат, 1962. Т. 6. 556 с.

4 Брюсов В. Я. Огненный ангел. М.: Скорпион, 1909. 374 с.

5 Брюсов В. Я. Собр. соч.: в 7 т. М.: Худож. лит., 1974. Т. 4.350 с. Т. 6.651 с.

6 Герчук Е. Ю. Архитектура книги. М.: IndexMarket, 2011. 206 с.

7 Герчук Ю. Я. История графики и искусства книги. М.: РИП-холдинг, 2013. 316 с.

8 Динерштейн E. А. Апология книге // Российское книгоиздание (конец XVIIIXX в.). М.: Наука, 2004. C. 11-21.

9 Завадская E. В. Хорхе Луи Борхес о книге как о феномене культуры // Книга. Исследования и материалы. М.: Книга, 1991. Сб. 62. С. 212-221.

10 Иоффе Д. Жизнетворчество русского модернизма sub specie semioticae. Историографические заметки к вопросу типологической реконструкции системы жизнь - текст // Критика и семиотика. Новосибирск; М.: Изд-во НГУ, 2005. Вып. 8. С. 126-179.

11 Кореикая И. В. Литература в кругу искусств // Русская литература рубежа веков (1890-е - начало 1920-х гг.). М.: ИМЛИ РАН, 2000. Кн. 1. С. 131-190.

12 Кореикая И. В. Литература в кругу искусств: полилог в начале ХХ в. М.: ИВИ PAH, 2001. $294 \mathrm{c}$.

13 Лещзинский А. А. Основы графики: учебн. пособ. Гродно: Изд-во ГрГУ, 2003. $194 \mathrm{c}$.

14 Мазаев А. И. Проблема синтеза искусств в эстетике русского символизма. М.: Наука, 1992. 324 с.

15 Нессельштраус Ц. Г. Первые европейские иллюстрированные книги (издания Альбрехта Пфистера в Бамберге) // Книга и графика: сб. ст. М.: Наука, 1972. C. $78-88$.

16 Пахомов В. В. Книжное искусство: в 2 кн. М.: Искусство, 1962. Кн. 2. 432 с.

17 Tолстых Г. А. Книготворческие взгляды русских поэтов-символистов // Книга. Исследования и материалы. М.: Книга, 1994. Сб. 68. С. 209-229.

18 Фаворский В. А. Литературно-теоретическое наследие. М.: Сов. художник, 1988. $588 \mathrm{c}$. 
19 Чудеиякая Е. В. Огненный ангел // Брюсов В. Я. Собр. соч.: в 7 т. М.: Худож. лит., 1974. T. 4. C. 341-349.

20 Шапошников М. Б. П. С. Соловьева. В. Я. Брюсов. М. А. Волошин. А. А. Блок. А. Белый. Кочевники красоты. М.: БОСЛЕН, 2016. 240 с.

21 Hottenroth F. Deutsche Volkstrachten, städtische und ländliche, vom XVI. Jahrhundert an bis zum Anfange des XIX. Jahrhunderts. Volkstrachten aus West- und NordwestDeutschland. 2. Auflage. Frankfurt am Main: Verlag von Heinrich Keller, 1923. 218 p.

\section{REFERENCES}

1 Barkovskaia N. V. Poetika simvolistskogo romana [Poetics of the symbolist novel]. Ekaterinburg, Izdatel'stvo UrGPU Publ., 1996. 285 p. (In Russian)

2 Barsht K. A. O tipologicheskikh vzaimosviaziakh literatury i zhivopisi (na materiale russkogo iskusstva XIX v.) [On the typological relationship of literature and art (on the material of Russian art of the $19^{\text {th }}$ century)]. In: Russkaia literatura i izobrazitel'noe iskusstvo XVIII - nachala XX v. Sobranie nauchnykh trudov [Russian literature and fine arts of the $18^{\text {th }}$ - early $20^{\text {th }}$ century. Collection of scientific works]. Leningrad, Nauka Publ., 1988, pp. 5-48. (In Russian)

3 Blok A. A. Sobranie sochinenii: $v 8 t$. [Collected works: in 8 vols.]. Moscow, Leningrad, Goslitizdat Publ., 1962. Vol. 6. 556 p. (In Russian)

4 Briusov V. Ia. Ognennyi angel [Fire angel]. Moscow, Skorpion Publ., 1909. 374 p. (In Russian)

5 Briusov V. Ia. Sobranie sochinenii: $v 7 t$. [Collected works: in 7 vols.]. Moscow, Khudozhestvennaia literature Publ., 1974. Vol. 4. 350 p. Vol. 6. 651 p. (In Russian)

6 Gerchuk E. Iu. Arkhitektura knigi [Collected works: in 7 vols.]. Moscow, IndexMarket Publ., 2011. 206 p. (In Russian)

7 Gerchuk Iu. Ia. Istoriia grafiki $i$ iskusstva knigi [Architecture of the book]. Moscow, RIP-kholding Publ., 2013. 316 p. (In Russian)

8 Dinershtein E. A. Apologiia knige [Apologies to the book]. In: Rossiiskoe knigoizdanie (konets $X V I I I-X X$ v.) [Russian book publishing (the end of the $18^{\text {th }}-20^{\text {th }}$ century)]. Moscow, Nauka Publ., 2004, pp. 11-21. (In Russian)

9 Zavadskaia E. V. Khorkhe Lui Borkhes o knige kak o fenomene kul'tury [Jorge Louis Borges on the book as a cultural phenomenon]. In: Kniga. Issledovaniia i materialy [Book. Research and materials]. Moscow, Kniga Publ., 1991, collection 62, pp. 212-221. (In Russian)

10 Ioffe D. Zhiznetvorchestvo russkogo modernizma sub specie semioticae. Istoriograficheskie zametki k voprosu tipologicheskoi rekonstruktsii sistemy zhizn' tekst [The life-making of Russian modernism sub specie semioticae. Historiographical notes on the typological reconstruction of the life-text system]. In: Kritika i semiotika [Criticism and semiotics]. Novosibirsk, Moscow, Izdatel'stvo NGU Publ., 2005, vol. 8, pp. 126-179. (In Russian)

11 Koretskaia I. V. Literatura v krugu iskusstv [Literature in the circle of arts]. In: Russkaia literatura rubezha vekov (1890-e - nachalo 1920-kh gg.) [Russian literature of the turn of the century (1890s - early 1920s)]. Moscow, IWL RAS Publ., 2000, book 1, pp. 131-190. (In Russian)

12 Koretskaia I. V. Literatura v krugu iskusstv: polilog v nachale XXv. [Literature in the circle of arts: polylogue at the beginning of the $20^{\text {th }}$ century]. Moscow, IVI RAN Publ., 2001. 294 p. (In Russian) 
13 Leshchinskii A. A. Osnovy grafiki: uchebnoe posobie [Fundamentals of graphics: textbook]. Grodno, Izdatel'stvo GrGU Publ., 2003. 194 p. (In Russian)

14 Mazaev A. I. Problema sinteza iskusstv v estetike russkogo simvolizma [The issue of synthesis of arts in the aesthetics of Russian symbolism]. Moscow, Nauka Publ., 1992. 324 p. (In Russian)

15 Nessel'shtraus Ts. G. Pervye evropeiskie illiustrirovannye knigi (izdaniia Al'brekhta Pfistera v Bamberge) [The first European illustrated books (editions of Albrecht Pfister in Bamberg)]. In: Kniga i grafika: sbornik statei [Book and graphics: collection of articles]. Moscow, Nauka Publ., 1972, pp. 78-88. (In Russian)

16 Pakhomov V. V. Knizhnoe iskusstvo: $v 2 \mathrm{kn}$. [Book art: in 2 books]. Moscow, Iskusstvo Publ., 1962. Book 2. 432 p. (In Russian)

17 Tolstykh G. A. Knigotvorcheskie vzgliady russkikh poetov-simvolistov [Bookmaking views of Russian symbolist poets]. In: Kniga. Issledovaniia i materialy [Book. Research and materials]. Moscow, Kniga Publ., 1994, collection 68, pp. 209-229. (In Russian)

18 Favorskii V. A. Literaturno-teoreticheskoe nasledie [Literary and theoretical heritage]. Moscow, Sovetskii khudozhnik Publ., 1988. 588 p. (In Russian)

19 Chudetskaia E. V. Ognennyi angel [Fiery angel]. Briusov V. Ia. Sobranie sochinenii: $v 7$ t. [Collected works: in 7 vols.]. Moscow, Khudozhestvennaia literature Publ., 1974, vol. 4, pp. 341-349. (In Russian)

20 Shaposhnikov M. B. P. S. Solov'eva. V. Ia. Briusov. M. A. Voloshin. A. A. Blok. A. Bely. Kochevniki krasoty [P. S. Solovyova. V. Y. Bryusov. M. A. Voloshin. A. A. Blok. A. Bely. The nomads of beauty]. Moscow, BOSLEN Publ., 2016. 240 p. (In Russian)

21 Hottenroth F. Deutsche Volkstrachten, städtische und ländliche, vom XVI. Jahrhundert an bis zum Anfange des XIX. Jahrhunderts. Volkstrachten aus West- und NordwestDeutschland. 2 Auflage. Frankfurt am Main, Verlag von Heinrich Keller Publ., 1923. 218 p. (In German) 